\begin{tabular}{|c|c|c|c|c|c|c|}
\hline \multirow{4}{*}{ Impact Factor: } & ISRA (India) & $=3.117$ & SIS (USA) & $=0.912$ & ICV (Poland) & $=6.630$ \\
\hline & ISI (Dubai, UAE & $=0.829$ & РИНЦ (Russia & $=0.156$ & PIF (India) & $=1.940$ \\
\hline & GIF (Australia) & $=0.564$ & ESJI (KZ) & $=8.716$ & IBI (India) & $=4.260$ \\
\hline & JIF & $=1.500$ & SJIF (Morocco & $=\mathbf{5 . 6 6 7}$ & OAJI (USA) & $=0.350$ \\
\hline
\end{tabular}

\begin{tabular}{|c|c|}
\hline $\begin{array}{l}\text { SOI: } \frac{1.1 / \mathrm{TA}}{} \\
\text { International Sc } \\
\text { Theoretical \& A }\end{array}$ & $\begin{array}{l}S \text { DOI: } 10.15863 / T A S \\
\text { ientific Journal } \\
\text { pplied Science }\end{array}$ \\
\hline p-ISSN: 2308-4944 (print) & e-ISSN: 2409-0085 (online) \\
\hline Year: 2019 & Volume: 72 \\
\hline Published: 30.04 .2019 & http://T-Science.org \\
\hline
\end{tabular}

SECTION 31. Economic research, finance, innovation, risk management
QR - Issue

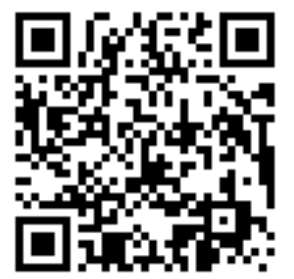

Omilhon Ismailov

Candidate of economics, Tashkent state pedagogical university, Tashkent, Republic of Uzbekistan

\title{
CONCEPTUAL BASES OF FORMATION OF COMPETITIVE ENVIRONMENT IN ENTREPRENEURSHIP ACTIVITY
}

\footnotetext{
Abstract: The article discusses the conceptual framework for the formation of a competitive environment in business. The author studied the issues of increasing the innovation potential and investment activity in the development of effective entrepreneurship.

Key words: competition, competitive environment, business, entrepreneurship, market, innovation.

Language: English

Citation: Ismailov, O. (2019). Conceptual bases of formation of competitive environment in entrepreneurship activity. ISJ Theoretical \& Applied Science, 04 (72), 430-446.

Soi: http://s-o-i.org/1.1/TAS-04-72-54 Doi: crossef https://dx.doi.org/10.15863/TAS.2019.04.72.54
}

\section{Introduction}

In the course of implementing large-scale market reforms implemented in Uzbekistan, the foundations were laid for the formation of a mixed economy, the main economic subject of which is an entrepreneur who rationally and effectively connects the factors of production in economic activity.

The main goal of the holistic "national economy" system at the present stage of reforms is to create the necessary institutional conditions to stimulate a competitive environment leading to the emergence of a powerful, economically efficient private sector.

The priority areas of state regulation of business activities include the creation of a legal framework and the provision of conditions for the realization of property rights and the formation of a competitive environment on this basis. Further development of entrepreneurship involves the openness of the economy, attracting foreign investment, the release of its own, competitive to world standards products. Equally important are the tasks of adjusting the distribution of resources, redistributing part of the income in accordance with social programs, ensuring economic stability, as an integral part of state stability as a whole, which are characteristic of any state with a market economy.

It should be noted (taking into account the experience of developed countries) that ensuring sustainable competitiveness of domestic producers is largely determined not only by the conditions for the emergence of a competitive environment, but also by the formation of a market psychology of top and middle managers.

The activity of the enterprise as a subject of market relations takes place under conditions of fierce competition between producers. It is the competitive market environment that creates the most favorable conditions for economic development, both for an individual enterprise and for society as a whole, is the driving force of social and economic progress. The coordinating and supporting influence of the state can provide the necessary result only if domestic entrepreneurship is focused on creating effective hightech industries that provide a new level of competitiveness, investment and innovation. Therefore, investment and innovation development has become one of the priorities of economic reforms carried out in Uzbekistan.

The adoption of a number of laws, the emergence of presidential decrees and resolutions of the Cabinet of Ministers, as well as their wide coverage in the media, testifies to the most serious attention that the government pays to business issues.

Small business contributes to the solution of many important national economic problems, including the employment of demobilized soldiers, youth and the disabled, the improvement of the ecological situation, etc. It is an integral part of a market economy. This type of business has a significant impact on the development of scientific and technical areas of life.. 


\begin{tabular}{|c|c|c|c|c|c|c|}
\hline \multirow{4}{*}{ Impact Factor: } & ISRA (India) & $=3.117$ & SIS (USA) & $=0.912$ & ICV (Poland) & $=6.630$ \\
\hline & ISI (Dubai, UAE & $=0.829$ & РИНЦ (Russia & $=0.156$ & PIF (India) & $=1.940$ \\
\hline & GIF (Australia) & $=0.564$ & ESJI (KZ) & $=8.716$ & IBI (India) & $=4.260$ \\
\hline & JIF & $=1.500$ & SJIF (Morocco & $=\mathbf{5 . 6 6 7}$ & OAJI (USA) & $=0.350$ \\
\hline
\end{tabular}

A feature of small business is its stability in times of crisis for large industrial production periods. The experience of developing countries shows that against the background of a protracted economic crisis, small enterprises producing mainly consumer goods suffer less than large ones and even strengthen their positions in the market, which makes them an important factor of economic and social stability.

Serious qualitative changes occur in solving the problem of employment. Along with the accelerated development of small business and private entrepreneurship, a large role is played by the development of the service sector, the widespread introduction of various forms of home-based labor, and the promotion of the development of animal husbandry in the countryside.

World experience in market economy shows that high efficiency of this model is achieved only when all major markets for goods and services, including at the regional level, grow large producers as if balanced by the necessary number of small and medium-sized producers. It is the latter that, to a decisive extent, ensure the formation and preservation of the market as a competitive environment for free enterprise, impede the tendencies of monopolization of markets, solve many social problems, above all, support employment of the population. A very remarkable aspect of the functioning of the market system is the interdependence of private and public interests. Firms and resource providers seeking to increase their own benefit and operate within a competitive market system at the same time contribute to ensuring the public interest. So, the power of competition controls or directs the motive of personal gain in such a way that it automatically and involuntarily contributes to the best satisfaction of ensuring the interests of society.

A specific feature of the current stage of reforms is the development of a theoretical basis for the formation of programs for the implementation of institutional reforms (both partial ones within individual sectors of the economy and large-scale ones covering the entire economic system of the republic).

Institutional provisions in their totality represent legitimate conditions for the choice by economic entities of production factors, types, forms and methods of their participation in the processes of a market economy, their relations with each other and other actors of society. The development of an effective economic mechanism for the formation of a competitive environment in the national economy must precede any more or less serious reforms. It should be considered primarily as a system of functional economic forms of adjusting the development of socio-economic processes, the contents of which are the real production relations of economic entities in a regulated market processes. At the same time, it is presented as a fairly reasonable methodology for further research of market problems and their systematic solution in the course of economic and social reforms based on pluralism of ownership forms and equality of all subjects of market processes.

The process of institutional transformations involves, as a rule, the formation of institutions (rules and norms) ensuring the formation of:

* private property;

* clarity and sustainability in the allocation of responsibility (commercial law, civil code procedures, bankruptcy procedures, collateral, etc.);

* control over the behavior of those who have the property of others in trust management (accounting system, banking operations, stock exchange transactions, operations in the securities market, etc.);

* control over the behavior and expectations of economic agents (which implies the formation of a new role of the state in the economy).

Further formation of the business environment presupposes, first of all, a clearly expressed political will to control the observance of the "rules of the game" by all participants, to general strengthening of market discipline, and at the same time transition to the implementation of a long-term strategy aimed at creating a system that ensures the conditions of "selfrealization" contractual obligations and centralized enforcement of private property rights.

Entrepreneurial activity involves government support, which is aimed at the conscious creation by government agencies of economic and legal conditions, incentives for the development and competitive strength of small businesses, and also the side - investing in it material and financial resources. State support should be manifested in reasonable subsidies, preferential tax treatment, lending, insurance, investment, etc. In this case, it will not be of the nature of encouraging dependency, and is considered by small enterprises as something permanent or as the main source of increased competitiveness and profitability. Under these conditions, the main principle of state support should be a gradual reduction of the administrative-directive regulation of business and the creation of primarily economic and legal conditions for the normal conduct of market economy. Government support should be expressed in the formation of economic and legal conditions, incentives for self-development and competitiveness of entrepreneurship, taking into account industry, geographical, national, historical features and traditions, as well as foreign experience. The most important tasks of state support for entrepreneurship are to ensure small businesses equal rights, minimize the gap in terms of economic opportunities between small and larger enterprises, ensure the optimal ratio of small and large businesses in the structure of the basic processes of formation of a market economic system of Uzbekistan. First of all, it is the creation of conditions for equality in competitive market competition, equal opportunities 


\begin{tabular}{|c|c|c|c|c|c|c|}
\hline \multirow{4}{*}{ Impact Factor: } & ISRA (India) & $=3.117$ & SIS (USA) & $=0.912$ & ICV (Poland) & $=6.630$ \\
\hline & ISI (Dubai, UAE & $=0.829$ & РИНЦ (Russia) & $=0.156$ & PIF (India) & $=1.940$ \\
\hline & GIF (Australia) & $=0.564$ & ESJI (KZ) & $=8.716$ & IBI (India) & $=4.260$ \\
\hline & JIF & $=1.500$ & SJIF (Morocco & $=5.667$ & OAJI (USA) & $=0.350$ \\
\hline
\end{tabular}

for doing business in conditions of free choice of its forms and methods of manifestation of independence and enterprise, granting rights and clearly defined responsibility, opportunities and risk.. [47]

State support of entrepreneurship is a means of achieving the socio-economic goals of the current and future stages of development of the republic based on market mechanisms for organizing its economic system. Therefore, the general and milestone socioeconomic goals of the development of the country are at the same time the goals of state support for entrepreneurship. The real goal of economic reforms is the achievement of economic growth, the creation of an efficient economy ensuring a high standard of living of the population, the real participation of Uzbekistan in the world economic community.

In ensuring the sustainable development of the national economy, the measures taken to support small and private entrepreneurship are of no small importance. In recent years, a number of legislative acts have been adopted to improve and develop the regulatory framework for the development and support of business activities. They are mainly aimed at:

ensuring more full employment of the population in the sphere of production, expanding the share of the private sector in the economy of the country, as well as creating the necessary conditions for the rapid development of small business;

simplification of the process of registration and execution of documents giving the right to conduct business activities, the elimination of bureaucratic barriers;

creation of wide opportunities for further improvement of the system of financing and lending to small businesses and private entrepreneurship, ensuring the effective use of sources of credit resources;

introduction of market principles and mechanisms for product sales, liquidation of the centralized distribution system, provision of equal access to material and technical resources to all economic entities, regardless of the form of ownership, improvement of the mechanism of formation of market prices;

creation of wide opportunities for the development of the private sector in the economy of the republic and a cardinal increase in its role and importance;

Improving the business environment and expanding the legal, economic and financial freedom of private enterprises;

Assistance in establishing business relations of businessmen of the republic with foreign partners, active promotion of domestic goods and services to foreign markets;

attracting foreign investments to the republic for the creation of new, technical re-equipment and modernization of existing industries ensuring the production of competitive finished products.

At the same time, support for entrepreneurship is independent objectives arising from the special features of its objects. The main ones are: the widespread approval of the practice of fair competition; the formation of a wide social stratum of owners and entrepreneurs; creation of maximum selfrealization of citizens in business activities; forming infrastructure business to national, regional and local level, ensuring its effective growth; stimulation of promising directions for the development of entrepreneurship and priority activities; promoting the accumulation of investment resources and their use in priority areas; to ensure the participation of small enterprises in the implementation of major economic projects and programs, as well as in the supply of products and the performance of work for state needs; modernization of production assets of small enterprises, the introduction of advanced technologies and new equipment; sustainable functioning of small business in a competitive environment by reducing the impact of higher commercial and financial risks related to entrepreneurship. It must be emphasized that all these objectives can not be considered and implemented separately in time, because they are interconnected, and therefore should be carried out together and simultaneously. The implementation of these in conjunction with regional and sectoral level interventions should improve the business value of the country's economy.

The main directions of state support of business, regardless of industry sector and activities are:

- the creation of equal conditions for business access to financial, material and technical and information resources,

- as well as to scientific and technical developments and technologies;

- assistance in organizing training, retraining and advanced training for managers, specialists and personnel of enterprises;

- the support of foreign economic activity of business entities, including the promotion of their trade, scientific, technological, industrial, information links with foreign countries, as well as attracting foreign investment to the development of entrepreneurship;

- establish a simplified procedure for registration of business entities, licensing of their activities and the provision of statistical reports;

- formation and implementation of national, sectoral and regional programs aimed at saturation of the market of environmentally friendly and safe products, competitive means of production.

It should be noted that support for entrepreneurship is a challenge not only government agencies, but also no less objective regions. It is in the regions under the conditions of an emerging market that the task of social and economic development of territories is being solved. Effective market economy 


\begin{tabular}{|c|c|c|c|c|c|c|}
\hline \multirow{4}{*}{ Impact Factor: } & ISRA (India) & $=3.117$ & SIS (USA) & $=0.912$ & ICV (Poland) & $=6.630$ \\
\hline & ISI (Dubai, UAE & $=0.829$ & РИНЦ (Russia) & $=0.156$ & PIF (India) & $=1.940$ \\
\hline & GIF (Australia) & $=0.564$ & ESJI (KZ) & $=8.716$ & IBI (India) & $=4.260$ \\
\hline & JIF & $=1.500$ & SJIF (Morocco & $=5.667$ & OAJI (USA) & $=0.350$ \\
\hline
\end{tabular}

in the region is possible only on the condition that on the monopolistic structure of the goods and services markets, supplemented and, to some extent counterbalanced by the necessary number of private enterprises, including small and entrepreneurship. Such enterprises ensure the preservation of the market as a competitive environment and contribute to solving social problems in the region. In this regard, the problem of the development of entrepreneurship, versatile support in this sphere should be counted among the most important tasks of public policy, at both the national and regional levels..

The regulatory role of the state in the sphere of entrepreneurial activity involves the conduct of antitrust policy. The basis of the state measures that form the anti-monopoly policy should be a common conceptual view, according to which the highest wellbeing of citizens is achieved when they have the opportunity to freely exchange goods and services produced by them in a competitive market. Moreover, it is believed that if all transactions on such exchanges are concluded on the basis of prices established as a result of competition between suppliers of goods and services, the society as a whole will receive a greater amount of material benefits than in the case when part of such transactions will be concluded at prices deviating from the competition in the direction of both overvaluation and underreporting. The competitive market, therefore, acts as a universal regulator of social production, its proportions. At the same time, the question of what to produce and in what quantity is objectively decided by the consumer himself, presenting a demand for certain types of goods and services in the market.

Solving the problem of antitrust law to support competition at the same time implies preventing the market state from which its functions cease to function - establishing a monopoly on it. Moreover, a monopolist is not necessarily understood as a very large corporation, but a company of any size, protecting itself from the action of the abovementioned competitive functions through restrictive practice, i.e. measures that prevent rival companies from entering the market where it operates. Such measures include the seizure of sources of raw materials and distribution channels, as well as various agreements (cartels) between two or several companies, aimed at ousting the rest from the market and preventing new competitors from penetrating it, dividing it among themselves and a number of others. Prevention of restrictive practices implemented in one form or another is the immediate goal of the antimonopoly defense system of society.

Competitiveness is a key factor and important economic dimension of sustainable and consistent development of any national economy. Increasing the competitiveness of the national economy plays an important role in determining the role of the country in the world economy and taking the place among the developed countries.

It is in this direction that there are a number of microeconomic factors that are widely used in world practice and have their own effect. The market economy requires competition, regardless of its maturity and developmental characteristics. Competition is the most important sign of the commodity and market economy, the means of its development.

\section{Literature review}

Understanding the economic context of competition requires a different approach to it.

Competition is a competition of business entities (competitors), in which the independent actions of each of them are based on the general conditions of the commodity circulation in the commodity and financial markets, one-sided exclude or limit the ability to influence effectively "[1].

The purpose of this law is to regulate relationships in the field of competition in the commodity and financial markets, which is aimed at legitimate competition and fraudulent competition between different types of ownership, but the same product (s) of production. According to A. Smith, "Competitiveness is a fair competition between market agents to sell the product under the most favorable conditions" [12]. M. Weber states that "Competition is an attempt to control the capabilities and capabilities of others" [47].

According to A. Smith and M. Weber's discourse, the content of competition is the advantage of the opponent, and the object of competition is the ability to buy resources, resources, and consumers. "Competitiveness is a struggle between innovation and old style," says Schumpeter.

According to the competitiveness of competition, "Competitiveness - Innovation, New Opportunities and Satisfaction" (I.Kirtsner) or "Competition is the invention procedure" [16]. According to Sh. Ergashhodjaeva, "Competition is a social category and represents a struggle for better living conditions among the participants of social processes" [9].

The nature of competition, the position of the market and the approach to the development process are the basis of separate approaches. It uses static and dynamic competition. Static competition is a structured approach, dynamic competition behavior, business environment, functional and evolutionary approach (Graph 1).

Thus, competition is a multifaceted economic phenomenon that represents a complex relationship between all market subjects. In our view, it is the struggle between market entities to clash with competitive economic interests or to gain high profits, to achieve image and fidelity. 


\begin{tabular}{|c|c|c|c|c|c|c|}
\hline \multirow{4}{*}{ Impact Factor: } & ISRA (India) & $=3.117$ & SIS (USA) & $=0.912$ & ICV (Poland) & $=6.630$ \\
\hline & ISI (Dubai, UAE & $=0.829$ & РИНЦ (Russia & $=\mathbf{0 . 1 5 6}$ & PIF (India) & $=1.940$ \\
\hline & GIF (Australia) & $=0.564$ & ESJI (KZ) & $=8.716$ & IBI (India) & $=4.260$ \\
\hline & JIF & $=1.500$ & SJIF (Morocco & $=5.667$ & OAJI (USA) & $=0.350$ \\
\hline
\end{tabular}

Experts say that "the most important sign of a competitive market economy and, in general, a commodity, is a way to develop."

According to Wright, "competitive firms are struggling for a limited-paying supply or a combination of uncertainties in a number of independent business units."

In his teachings, the function of competition depends on the choice of technology, the choice of production, and helps to understand the information about this market. The role of competition plays an important role in ensuring the harmonization of supply and demand and ensuring sustainability.
According to the evolutionary interpretation of competition, "it is a dynamic process to search for effective forms of competition behavior and to simultaneously select them."

Competition between manufacturers ultimately means struggle for attracting consumers.

\section{Analysis and results}

Competition also happens to consumers: they try to buy goods at affordable prices, which means that the buyer strives to gain more profit from the spent money. These relationships can be described as follows (Graph 1).

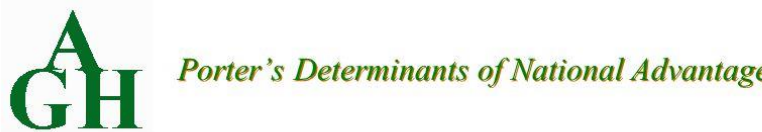
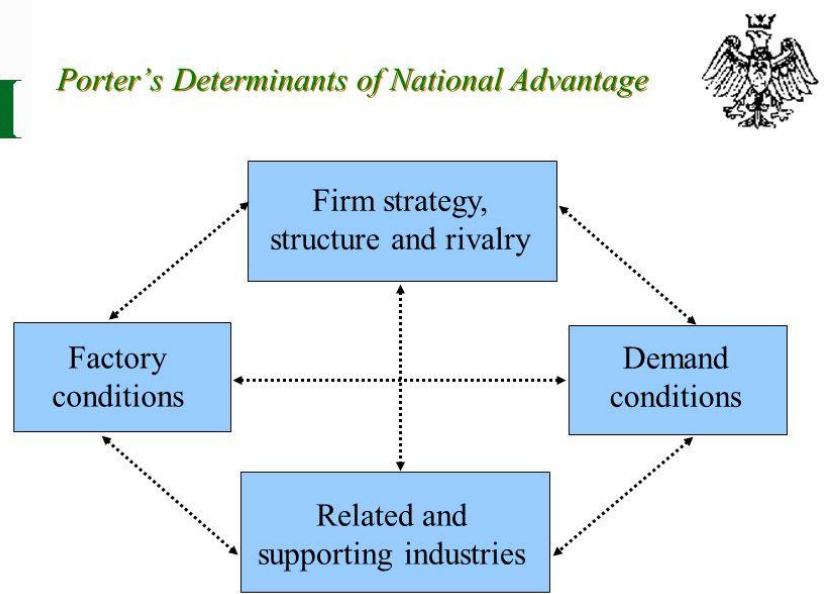

Advantage of Nations, by Michael E. Porter. Copyright 01990 by Michael E. Porte

Fig. 1. The main objectives of competition participants.

It is clear from the drawings that the struggle for the benefit of each of the costs incurred by the producers will be more likely. As a result of these benefits, they are fighting for the sales of commodities, ie favorable markets, cheap raw materials, energy, and cheap labor.
The concept of M. Porter. In 1982, M. Porter proposed the concept of enhanced competition (Graph 2).

According to him, the ability of the firm to use the competitive advantage of the market depends not only on the competition it faces, but also on the potential influence of potential market opponents, substitutes, customers, and suppliers.

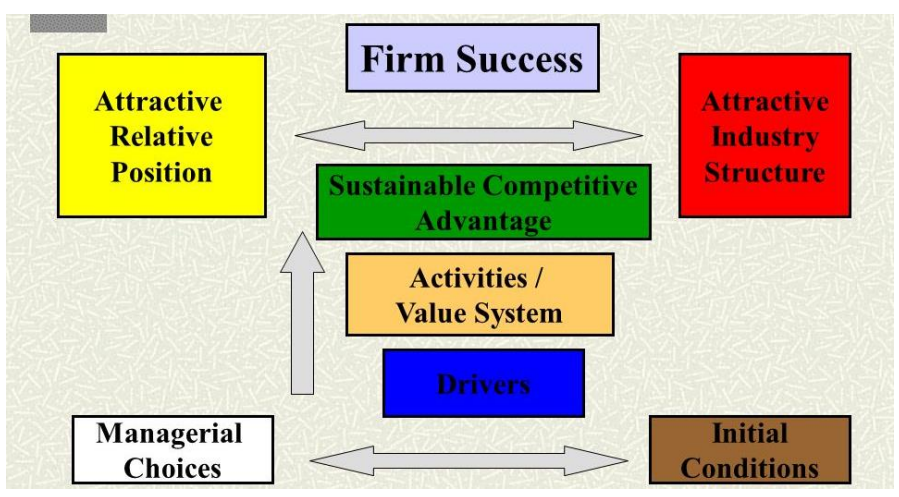

Fig. 2. M. Porter's Competition Concept. 


\begin{tabular}{|c|c|c|c|c|c|c|}
\hline \multirow{4}{*}{ Impact Factor: } & ISRA (India) & $=3.117$ & SIS (USA) & $=0.912$ & ICV (Poland) & $=6.630$ \\
\hline & ISI (Dubai, UAE & $=0.829$ & РИНЦ (Russia & $=0.156$ & PIF (India) & $=1.940$ \\
\hline & GIF (Australia) & $=0.564$ & ESJI (KZ) & $=8.716$ & IBI (India) & $=4.260$ \\
\hline & JIF & $=1.500$ & SJIF (Morocco & $=\mathbf{5 . 6 6 7}$ & OAJI (USA) & $=0.350$ \\
\hline
\end{tabular}

In-competition competition means that among firms entering the same network, the favorable conditions for the production and sale of commodities is to fight for good profit.

Because of the varying levels of technical level and productivity of the enterprises in each industry, the individual value of the goods they produce is also varied. The Commodity Value Act applies, so different individual values are brought to the social market value.

In economic literature, four forms of competition within a network are highlighted separately. These are free competition, monopolistic competition, pure monopoly and oligopoly [6].

In the conditions of free competition, there are many enterprises producing the same product in the network. Under free competition conditions, new businesses are free to enter the network or existing enterprises in the network can leave it freely. There are no legal, technological, financial, or other serious economic barriers to the emerging new businesses to sell their competitive products on the market.

Monopolistic competition involves both monopoly and competition. Dozens of manufacturers of one type of product in the network compete with each other for a reasonable price and production capacity. At the same time, each producer will become a monopoly producer by differentiating its product, ie by distinguishing between any other product (quality, shape, packing, selling conditions, etc.) of such products.

Because pure monopoly is a single company or a manufacturer, it is the sole producer and the sole proprietor of existing products.

The most important sign of oligopoly is the presence and domination of so many businesses in the industry.

In the conditions of oligopoly, competition between enterprises will be interrelated. No firm in the oligopolistic sphere can focus on changing its pricing policy.

These four forms of competition within the network we are looking at are not purely in the national economy.

Interdisciplinary competition is a struggle for the highest possible profitability among firms and manufacturers in different industries.

Interdisciplinary competition is for capital to be invested in good sectors. Where there are more benefits, resources are flowing here. Therefore, the demand for the goods here will be high and will bring good benefits.

Another type of competition is informal, that is, an outrageous competition, condemned by the society. Firms and manufacturers in microcircuits sometimes use unlawful methods to compete in the competition. At the same time they act against the rules applied by the state in the regulation of competition. According to this, the following can be included in the illicit methods of unfair competition (Graph 4).

The urgency and effectiveness of increasing the competitiveness of industrial enterprises in the context of ever-changing demand of the consumer market depends on:

- Ensuring the production of high-quality products meeting the requirements of international and national standards and satisfaction of needs of consumers (buyers);

- expansion of commodity markets and increasing export volumes;

- Creating safe working conditions by ensuring the safety and reliability of technological processes.

In other words, the development of competition, which is one of the most important elements of the market economy, is an important guarantee of increasing the efficiency of economic activity of the non-economic entities.[48,49]

Competition in the economy is a process of making good profits, filling the abilities and opportunities for self-employment. Indeed, the main goal of increasing the national competitiveness is to be able to achieve effective industrial efficiency and to increase export potential, rationally using existing natural and human resources in the country.

It is possible to increase the competitiveness of the national economy in the country not only in the domestic market, but also in the foreign markets, to create a competitive environment and to achieve a competitive edge in the international competitive environment. In our opinion, the achievement of the strategic goals of increasing the competitiveness of domestic industrial products in the process of integration of Uzbekistan into the global economy system - in turn, requires the need to improve the organizational, economic and scientificmethodological foundations of ensuring that the industry meets the requirements of the international quality standard.

Experts point out that systematic marketing research and introduction of a quality management system and consistent development enable the following positive outcomes:

- Ensures timely compliance of production to market and consumer needs;

- improves the consumer properties and quality of the products produced.

According to N. Khalilov, [8] it is desirable to introduce the international standard requirements in general, including the number of employees and the type of product, in any industry, enterprise or organization.

M.Cauchik underlined that the introduction of quality management system and international standards included the following steps [13]:

Stage 1. Carry out a diagnostic audit of the company's compliance with ISO 9001: 2008. This determines the compliance of the business 


\begin{tabular}{|c|c|c|c|c|c|c|}
\hline \multirow{4}{*}{ Impact Factor: } & ISRA (India) & $=3.117$ & SIS (USA) & $=0.912$ & ICV (Poland) & $=6.630$ \\
\hline & ISI (Dubai, UAE & $=0.829$ & РИНЦ (Russia) & $=0.156$ & PIF (India) & $=1.940$ \\
\hline & GIF (Australia) & $=0.564$ & ESJI (KZ) & $=8.716$ & IBI (India) & $=4.260$ \\
\hline & JIF & $=1.500$ & SJIF (Morocco & $=5.667$ & OAJI (USA) & $=0.350$ \\
\hline
\end{tabular}

management system with the requirements of ISO 9001: 2008 .

Stage 2. Staff training to ISO 9001: 2008. The essence and requirements of ISO 9001 are taught. The working group is formed and its responsibility is determined.

Stage 3. Development of ISO 9001: 2008 SMT documentation. The main purpose of this is to document the transition stage to ISO 9001: 2008.

Stage 4. Implementation of ISO 9001: 2008 SMT. At the same time, employees of the organization or organization are trained and introduced into operation of ISO 9001: 2008.

Stage 5. ISO 9001: 2008 SMT analysis. In this case, internal auditors are trained to conduct an SMT audit and determine the degree of readiness of the SMT to certify.

Stage 6. Carry out an ISO 9001: 2008 Certification audit. At this stage, short-term certification audit, cost optimization, and ultimately ISO 9001: 2008 certification.

It should be noted that today the lack of interest in the implementation of international standards, lack of qualified managers and specialists in this direction creates a number of problems in the implementation of international standards in many enterprises.

At the moment, in order to further expand the production of stable demand on the domestic and foreign markets of the republic, and to organize the production of high quality and competitive products, a great attention is paid to the introduction of international standards in enterprises.

Experts point out that Uzbekistan has a mandatory and voluntary certification scheme, with a leading position in the quality management practice of ISO 9001: 2008 and its market share of $85 \%$.

The State Program for the Development of National Quality Infrastructure for the period up to 2020 has identified current trends in the introduction of quality management systems in the real sector of the economy, which includes the following efforts:

- Promotion of introduction of information and communication technologies and software in the agency "Uzstandart";

- Accreditation of 12 laboratories at the international level in food, chemical, electrical, machine building, construction and light industry;

- Also, development and introduction of 174 international standards.

As a result, so far, the following standards have been issued for certification [2]. Including:

- ISO 9001: 2008 - 2096 SMT certificates;

- ISO 47001: 2004 on environmental management standard - 47 SMT certificates;

- OHSAS 18001: 2007 with the International Standard on Occupational Safety and Health Management - 60 SMT Certificates;
- ISO 22000: 2005 with the International Standard on Food Safety Management - 47 SMT certificates.

As a result, the range of products with added value, which is demanded in domestic and foreign markets, has been increasing [17]. This can only be attributed to the examples of achievements in the field of fruit and vegetable processing.

In our opinion, the relevance and relevance of quality management in the food industry enterprises related to the storage, processing of fruits and vegetables in our country is explained as follows:

1. The need to improve the product quality and constantly improve it. As you know, the existing quality assurance system identifies and improves the reasons for the decline in product quality.

2 . The need to regularly reduce production costs and increase competitiveness. As a result of improved quality and productivity increase, the likelihood of the products being consumed to use is diminished, thereby reducing the cost of raw materials and materials and the amount of potential losses;

3 . The need to improve the management system in enterprises. Experts believe that 80 percent of products fail to meet the quality requirements of the product, and 20 percent depend on the executive branch.

At the same time, it is obvious that the role of domestic enterprises in their compliance with international quality standards and standards - their role in the international marketplace is undoubtedly a must.

In other words, the introduction of quality management system (SMT) at enterprises is an important guarantee for the quality of produced products and services, development of competing competition among the most important elements of the market economy and increasing the efficiency of economic activity of businesses.

It is important to know the ways in which entrepreneurs operating under the conditions of market relations are to be identified and analyzed as a result of free competition and to ensure their safe operation.

Each entrepreneur plans to earn a certain amount of income during his / her career. It does not spontaneously spell, it requires spending some money. The goal of the entrepreneurial income is to cover its expenses and make a profit. If the earnings just cover the expense $(D=X)$, it indicates that the entrepreneur has been hurt. If $(\mathrm{D}>\mathrm{X})$ the entrepreneur is working on this, if $(\mathrm{d}<=" " \mathrm{p}=$ " ">

In order to improve, evaluate and analyze the organizational, economic and social relationships required, it is necessary to identify the level of harm to the entrepreneur.

At the same time, it is necessary to develop an automated information system (AAT) program for the correct solution of problems of analysis and 


\begin{tabular}{|c|c|c|c|c|c|c|}
\hline \multirow{4}{*}{ Impact Factor: } & ISRA (India) & $=3.117$ & SIS (USA) & $=0.912$ & ICV (Poland) & $=6.630$ \\
\hline & ISI (Dubai, UAE & $=0.829$ & РИНЦ (Russia & $=\mathbf{0 . 1 5 6}$ & PIF (India) & $=1.940$ \\
\hline & GIF (Australia) & $=0.564$ & ESJI (KZ) & $=8.716$ & IBI (India) & $=4.260$ \\
\hline & JIF & $=1.500$ & SJIF (Morocco & $=5.667$ & OAJI (USA) & $=0.350$ \\
\hline
\end{tabular}

management with the use of modern information systems.

Determining the level of enterprise's vulnerability in the development of the program will be organized as a separate module. In this case, the composition of entrepreneurial income is determined first of all.

Entrepreneur income can be divided into the following elements:

- reimbursement of business expenses (X);

- payments to the state budget (C);

- arranging profits $(\mathrm{F})$.

In this case the following equation is formed:

$\mathrm{D}=\mathrm{X}+\mathrm{C}+\mathrm{F}(1)$

As can be seen from this formula, the entrepreneur's income is proportional to its costs, taxable income, and its profits. Which of these can be (if it is low), the size of the income may also increase. Using this simple equation, the first module and base for determining the level of business vulnerability will be developed. Developed base can be used to determine the degree of utilization of any business activity.

Information base software will be created in econometric modeling of costs and taxes. As we know, some of the costs and taxes are variable and some are unchanged.

The following figure shows the actual size of the result and factors that are expressed in the following formula.

$$
D=\left(X_{u z}+X_{u m}\right)+\left(C_{u z}+C_{u m}\right)+F
$$

As you can see, this formula differs greatly from the formula above.

Here are some of the following:

Crude - constant costs;

The Variable Surplus of Currencies;

An integral part of taxes.

If you want to create a base module together by adding the variable $(\mathrm{Xuz}+\mathrm{Cuz})$ and $(\mathrm{Xum}+\mathrm{Cum})$ in this formula, the following formula.

$$
D=\left(H_{u z}+H_{u m}\right)+F
$$

$\mathrm{Huz}=\mathrm{Xuz}+\mathrm{Cuz}$, Hum $=$ Khum + Cum. The relation of these factors to the income level is as follows: the increase in income increases the variable costs. Increasing the cost of variable costs will result in the final outcome. It can be used to calculate the correct coefficient $(\mathrm{Km})$. Then the 3 formulas will have the following formulas:

$$
D=K_{m} * H_{u z}+H_{u m}+F
$$

To determine the coefficient of variability, variable product costs are added together with a variable tax part (Huz) divided by its value:

$$
K_{m}=\frac{H u z}{\mathbf{P}}
$$

According to this formula, it is possible to calculate how much income a businessman should cover to cover all his expenses, such as his or her disadvantages. For this purpose, the first "gain point" of income (Dtn) is defined, that is, the amount of revenue should be sufficient to cover all expenses. There is no benefit in this. Then the 4 formulas are represented as follows:

$$
D=K_{m} * H_{u z}+H_{u m}
$$

The formula 6 can be written as follows to accurately represent the coefficient of correlation between the result and the factor:

$$
D^{t n}=\frac{H_{u m}}{1-K_{m}}
$$

According to this formula, it is possible to determine how much the entrepreneur should earn for covering all costs and tax collection.

In order to clarify the issue, the businessman analyzes the status of one product. In practice, entrepreneurs can also engage in the production and sale of several goods at the same time. In this case the harmful performance of the enterprise will be determined by the results of activities related to the production and sale of all goods. In this case we will use the following formula:

$$
\mathrm{D}^{t n}=\sum_{k=0}^{n}\left(\mathrm{D}_{k}^{n}-\mathrm{Huzi}\right)-\mathrm{H}^{u m i}
$$

In this case, the goods generated by the goods;

Variable expense for the production and sale of express goods;

Humidity - the actual amount of all permanent immovable costs;

$\mathrm{i}$ - number of order groups $(i=1, n)$;

$\mathrm{n}$ - the total number of manufactured and sold brands.

In practice, it is difficult to calculate revenue and expenses for each product. This is because of the total amount of revenue and expenses.

Then, the calculation of the financial result $(F)$ will be simplified and the following formula should be used:

$$
F=D^{t}=\left(\frac{H_{u m} * Y_{z}}{100}+H_{u m i}\right)
$$

Where $\mathrm{D}$ is the actual amount of the quarterly income;

HUM - Amount annual interest rate;

$\mathrm{Yz}$ - share of unimpaired expenses in the fourth quarter;

Hui - actual amount of variable costs per quarter:

It is possible to carry out modeling of the given stages. It is necessary to indicate that the coefficients and values of the given sequence are related to the values of common factors. For this purpose, it is envisaged to identify the factors affecting production processes.

Once the econometric models have been identified, reports of the selected objects will be 


\begin{tabular}{|c|c|c|c|c|c|c|}
\hline \multirow{4}{*}{ Impact Factor: } & ISRA (India) & $=3.117$ & SIS (USA) & $=0.912$ & ICV (Poland) & $=6.630$ \\
\hline & ISI (Dubai, UAE & $=0.829$ & РИНЦ (Russia) & $=0.156$ & PIF (India) & $=1.940$ \\
\hline & GIF (Australia) & $=0.564$ & ESJI (KZ) & $=8.716$ & IBI (India) & $=4.260$ \\
\hline & JIF & $=1.500$ & SJIF (Morocco & $=5.667$ & OAJI (USA) & $=0.350$ \\
\hline
\end{tabular}

obtained to reflect the relevance of the models to entrepreneurs and to reflect the economic processes. So, next task is to develop a set of econometric models.

This requires:

- Data obtained for modeling should be in the same range as the results obtained. Also, it should be noted that the more information received (by years), the greater the chance of achieving accuracy in the results;

- a set of econometric models that selects statistical information, reports and other official documents that combine socio-economic indicators with specific periods of production of the selected production facility, with the main sources of information, the quantitative indicators required for continuous and simultaneous modeling, and comparative to be in the nature of the character.

In addition, the database software for econometric modeling is used as a ready-made package of data analysis and application software (EXCEL, PHP) of modern computer techniques. Thus, it is expedient to solve the quantitative parametres of business efficiency using a comprehensive and systematic approach to econometric modeling and its formation in determination of future indicators.

Increasing innovation potential and investment activity in the development of effective entrepreneurship

The economic development, economic independence of each country, the living standards of the country's population and the employment rate of the population depend on the development of small business and private entrepreneurship. This situation is characterized by the development of the level of stimulation of economic freedom of the entrepreneurs.

Extensive activities are also being undertaken in our country to create a business environment, support and further stimulate entrepreneurship. As a result of the measures taken in 2017, more than 38.2 thousand subjects of small business were established or increased by $122.0 \%$ compared to 2016 . The largest share of these small business entities was in the industrial sector (27 percent), trade (21 percent), agriculture, forestry and fisheries (13 percent) and construction (10 percent).

The active use of the opportunities created by active entrepreneurs in the Republic to ensure the growth of finished goods production is achieved. According to the analysis, the share of small businesses and private entrepreneurship in the country's GDP in the year 2017 amounted to $53.3 \%$, while this figure rose to $56.2 \%$ in 2016 . The share of small business and private entrepreneurship in the sectors of economy in 2017 will reach $27.0 \%$ (in 2016
$-26.0 \%)$ and in industry $-39.6 \%(45.3 \%)$, services $58.4 \%(61.4 \%)$, construction $-65.1 \%(66.9 \%)$ and employment $-78.3 \%(78.2 \%)$.

There are problems with entrepreneurship in conjunction with achievements in the field. The role of innovation potential and increase of investment activity in the accelerated and sustainable development of business entities in our country is significant. Expected results in the long term are largely due to the rapid development of small businesses and private entrepreneurship. This ensures the growth dynamics of their products.

In order to ensure the growth of production by active entrepreneurs, the following activities should be undertaken:

- Creation of favorable innovative potential and investment climate on the basis of financial support of active entrepreneurship and enhancement of existing mechanisms and activation of new financing sources;

- Improvement of financial support of production organization in the active entrepreneurship;

- Improvement of mechanisms of foreign economic activity of active entrepreneurship;

- training of qualified competitive personnel for the active business, etc.

The President of the Republic of Uzbekistan Sh.M.Mirziyoev addressed the Oliy Majlis in the Address to the Oliy Majlis of the Republic of Uzbekistan as a new stage in our progress in 2017 and the address of the President of the Republic of Uzbekistan addressing the most important directions of socio-economic development in 2018: "Innovative innovative activities, and the economic direction, which is based on management methods. When it comes to businessmen, we are capable of producing competitive products, most importantly, create new jobs and understand business people who feed themselves and their families, but benefit the entire society. "[1] Indeed, the issue of expanding the ranks of entrepreneurs engaged in active entrepreneurship, including the introduction and introduction of high technology, techniques and equipment based on the latest achievements of science, is one of the most urgent tasks today. For this reason, it is necessary to ensure the continuity of the development of innovative activity.

Innovative capacities are related to the development of small enterprises. The world experience shows that small businesses produce more than 4 times more innovations than large enterprises or create smaller innovative enterprises for 2.5 times more than large enterprises for every dollar spent on research.

In the conditions of modernization of the economy, active entrepreneurs - the expansion of their ability to effectively use loans, raw materials, 


\begin{tabular}{|c|c|c|c|c|c|c|}
\hline \multirow{4}{*}{ Impact Factor: } & ISRA (India) & $=3.117$ & SIS (USA) & $=0.912$ & ICV (Poland) & $=6.630$ \\
\hline & ISI (Dubai, UAE & $=0.829$ & РИНЦ (Russia) & $=0.156$ & PIF (India) & $=1.940$ \\
\hline & GIF (Australia) & $=0.564$ & ESJI (KZ) & $=8.716$ & IBI (India) & $=4.260$ \\
\hline & JIF & $=1.500$ & SJIF (Morocco & $=5.667$ & OAJI (USA) & $=0.350$ \\
\hline
\end{tabular}

as well as public preferential systems - are an important factor in raising their innovative capacities.

The following aspects must be taken into account in the development of innovative entrepreneurship:

- Material and technical resources;

- tangible and intangible assets;

- financial resources;

- organizational resources;

- Personnel resources;

- Socio-psychological factors.

In view of the above, in order to establish innovative business processes of active entrepreneurship, at its discretion should have:

- Funds sufficient for financing the ideas and developments;

- Material and technical base for creation and mass production of new products;
- Capable of making and implementing innovations;

- Ability to develop original (formal) ideas based on any innovative process.

Increasing the innovative capacities of entrepreneurship is crucial to the growth of the country's industry and economy. Innovative and investment development is one of the key priorities for the implementation of technologies for the creation of innovation technologies, as well as the development of innovations. The economy is a part of investment projects implemented by the state-owned enterprises in the sector. expanded It is desirable to establish a fund for the preparation of project documentation on investment projects, which will allow businesses to reduce the costs of preparing business plans, improve their quality and reduce credit terms.

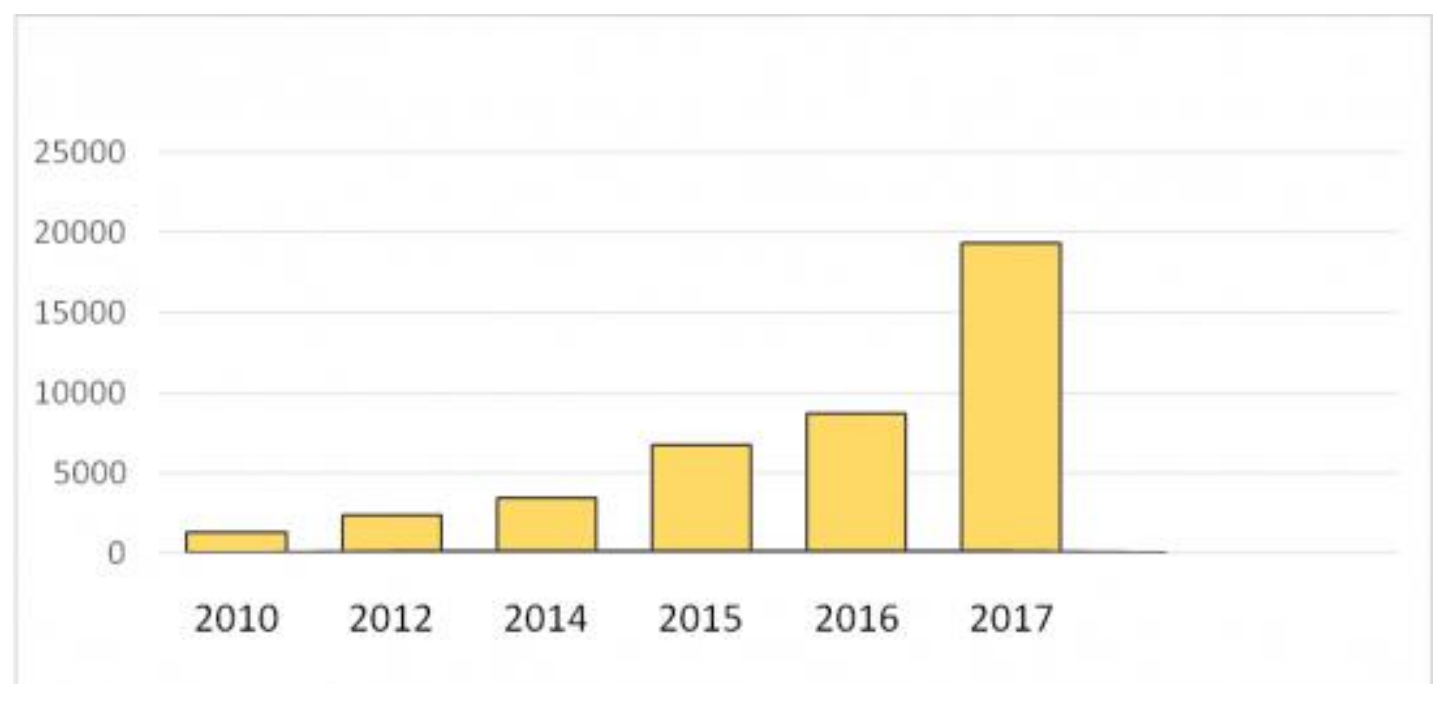

Graph 1: Characteristics of Small Business Investments.

Source: The author is based on the data from the State Statistics Committee of the Republic of Uzbekistan.

If we analyze trends characterizing small business investment in 2010-2017 (Graph 1), the current prices of fixed capital investments by them have a high rate of growth (15.0 times).

Also, the volume of products worth 1 billion soums increased by 6.6 times during this period. While this is a significant growth rate, this figure is significantly lower than in 2010-2017. This decline was due to the fact that during this period, the growth rate of investments in fixed capital by small businesses exceeded the rate of growth of their production.

Along with positive achievements in the field of small business investment, there are some problems in the development of active entrepreneurship. Including:
- lack of adequate technical and economic feasibility studies in some areas of active business;

- low level of use of long-term investment loans as a result of shortage of highly liquid mortgage facilities;

- the lack of the practice and the practice of statefunded loans to small businesses that produce and export goods in the priority sectors.

For this purpose, in our opinion, a comprehensive expertise of the proposed investment projects, the introduction of a mechanism of lending on the basis of guaranteed third-party guarantees, at least $50 \%$ of the interest rates of banks' loans, based on the refinancing rate of the Central Bank as a basic rate it is advisable to introduce the mechanism of bonus at the expense of funds. 


\begin{tabular}{|c|c|c|c|c|c|c|}
\hline \multirow{4}{*}{ Impact Factor: } & ISRA (India) & $=3.117$ & SIS (USA) & $=0.912$ & ICV (Poland) & $=6.630$ \\
\hline & ISI (Dubai, UAE & $=0.829$ & РИНЦ (Russia) & $=0.156$ & PIF (India) & $=1.940$ \\
\hline & GIF (Australia) & $=0.564$ & ESJI (KZ) & $=8.716$ & IBI (India) & $=4.260$ \\
\hline & JIF & $=1.500$ & SJIF (Morocco & $=5.667$ & OAJI (USA) & $=0.350$ \\
\hline
\end{tabular}

The role of small business and private entrepreneurship in economic sustainability

The announcement of the year 2018 as the Year of Support of Active Entrepreneurship, Innovative Ideas and Technologies in our country has created enormous opportunities for the development of small business and private entrepreneurship. Nowadays, it requires the development of entrepreneurship in the country in the conditions of global integration and globalization, innovation and modern approaches to small business, advanced technology and management methods.

In his address to the Oliy Majlis of the Republic of Uzbekistan, Shavkat Mirziyoev said: "When we say an active entrepreneur, we understand entrepreneurs who are able to produce competitive products and, most importantly, create new jobs and not only feed themselves and their families but also benefit the entire society. It is our first priority to expand the ranks of such entrepreneurs, to create the conditions for bringing them to our country and introducing advanced technology and science-based equipment and equipment. "

At the same time, the main directions of elimination of barriers that adversely affect the accelerated and sustainable development of small business and private entrepreneurship are being elaborated.

In our country, such rapid development of small business and private entrepreneurship, first of all, tax incentives for the sector are encouraging. In particular, in 2016, the single tax payment for small-scale industrial enterprises was reduced from 8 to 7 per cent, while for individual entrepreneurs this figure was reduced by an average of 1.3 times. Also, between 1996 and 2016 the tax rates for small business and private entrepreneurship declined from $38 \%$ to $5 \%$, ie 7.4 times.

The single tax payment is the only type of tax that is simplified in exchange for various taxes and duties to support small businesses.

As President Islam Karimov put it, "In our country the Ombudsman for the protection of the rights of entrepreneurs has been introduced. Business taxes have been dramatically reduced, expanded access to credit.

New free economic zones have been created, where investors have been given a wide range of benefits. "

Creation of favorable conditions for attraction of foreign and local investments in organization of modern production of mineral raw materials and processing of agricultural resources, providing production of competitive products with high added value in foreign markets, as well as in Samarkand, Bukhara, Ferghana and Khorezm with a view of complex and effective use of production and resource potential of the regions of the Republic of Uzbekistan, on this basis, to create new jobs and increase the incomes of the population, d Urgut district "Urgut" Gijduvan district of Bukhara region, "Gijduvan in Kokand, Ferghana region," "Cocaine", Khorezm region "Hazorasp" free economic zones in the district.

In accordance with the Decree of the President of the Republic of Uzbekistan of January 17, 2017 "On measures to accelerate the sale of state-owned facilities for business use and further simplify its procedures", the generalized taxes will be paid from the moment of signing the purchase and sale agreement of buyers of state-owned property objects Exemption from property tax and land tax on newly acquired state property for a period of 12 months, Steiermark objects of modernization, technical and technological re-equipment and development have been outlined are targeted.

In 2016, efforts were also made to reduce the costs associated with organizing business. For example:

- the cost of obtaining the architectural and planning task packages - 4 times;

- cost of expertise of design estimates - 2.5 times;

- the cost of registration of cadastral documents -2 times.

Measures on financial support of small business and entrepreneurship have been intensified. In particular, in 2016, small businesses and private entrepreneurship will receive about 1 trillion soums. $850 \mathrm{bn}$. Over UZS worth of loans were issued.

In the practice of the developed countries, the funds of credit institutions are a major source of financing for the development of small businesses. The share of commercial banks in foreign countries is financed by small businesses and private entrepreneurship. For example, small business loans in South Korea as of January 1, 2013, are 38.9 percent of GDP, 33.7 percent in Thailand, and 20.1 percent in Malaysia. The share of small businesses in the total volume of loans issued by banks is $30-40 \%$ in countries such as China, South Korea, Thailand and Indonesia, Malaysia and Kazakhstan, almost $20 \%$. Experience of developed countries shows that active state policy on forming and developing an effective financial infrastructure to provide small businesses with investment funds is required. According to foreign experience, effective support for small businesses can be accomplished through a broader mandate, financial means, and a specialized agency with branches throughout the country. Nowadays, economically developed countries are more often used indirectly to support small businesses directly with financial support. We'll look into the credit guarantee system in the following chart agency.

Small business enterprise Small and Medium Enterprise (Small Business Enterprise, Small Business Enterprise, SBA), Small and Medium Enterprise (Small and Medium Enterprise), Small and Medium Enterprise State Agency for Financing Small Business in South Korea and the Czech Republic, a 


\begin{tabular}{|c|c|c|c|c|c|c|}
\hline \multirow{4}{*}{ Impact Factor: } & ISRA (India) & $=3.117$ & SIS (USA) & $=0.912$ & ICV (Poland) & $=6.630$ \\
\hline & ISI (Dubai, UAE & $=0.829$ & РИНЦ (Russia) & $=0.156$ & PIF (India) & $=1.940$ \\
\hline & GIF (Australia) & $=0.564$ & ESJI (KZ) & $=8.716$ & IBI (India) & $=4.260$ \\
\hline & JIF & $=1.500$ & SJIF (Morocco & $=5.667$ & OAJI (USA) & $=0.350$ \\
\hline
\end{tabular}

Private Equity Credit Institution in Germany, the Agency for Entrepreneurship Development in Poland (PARP), Trade and Industry in Singapore at the Ministry of Entrepreneurship Development Agency (Spring), "Entrepreneurship Development Fund" JSC in Kazakhstan, Belarus (Damu), referred to as the "Entrepreneurship Fund for financial support".

The prospects for the development of small business and entrepreneurship have a great potential in the country, which is a sign of the year 2018 as the Year of Support for Active Entrepreneurship, Innovative Ideas and Technologies and, as a consequence, the adoption of the State Program.

Over the next two or three years a number of normative-legal documents on support and further development of small business and entrepreneurship have been adopted and put into practice. In accordance with the Decree of the President of the Republic of Uzbekistan of October 5, 2016 "On additional measures to ensure accelerated development of entrepreneurship, comprehensive protection of private property and qualitative improvement of the business environment", legal regulation of entrepreneurship, reduction of inspections of business entities, prevention of unreasonable interference, further liberalization of business entities' liability, financial and taxation changes and privileges in the field of improvement of customs and customs, enhancement of judicial protection of entrepreneurs, improvement of business environment, investment attractiveness and international rating of the republic. Thus, from January 1, 2017, all types of non-scheduled inspections of entrepreneurs (except for short-term inspections, conducted in accordance with the Decree of the Republican Council on coordination of controlling bodies on the basis of appeals of physical and legal entities on cases of violation of legal entities) are invalidated. were removed. For the first time, persons who have committed offenses related to the illicit entrepreneurship activity have been released from administrative and criminal penalties for voluntarily covering the damages within one month from the date of detection of the offense, as well as issuing the necessary documents, registered and authorized by the business entity. Failure to complete the barriers to effective functioning of the bank, as well as to ensure the full realization of the right of clients to freely dispose of their money, was adopted on January 3, 2017, the Law of the Republic of Uzbekistan "On Combating Corruption"..

Table 1. Infrastructure facilities, which provide services to entrepreneurs in Uzbekistan (as of January 1, 2017, unity)

\begin{tabular}{|l|c|}
\hline \multicolumn{1}{|c|}{ The name of the infrastructure object } & The number \\
\hline Affiliates of commercial banks & 1042 \\
\hline Minibanks & 2318 \\
\hline Information and consulting centers & 262 \\
\hline Consulting centers & 327 \\
\hline Audit firms & 113 \\
\hline Training Centers & 917 \\
\hline Evaluation companies & 138 \\
\hline Trading platforms of the Commodity Exchange & 204 \\
\hline Microcredit organizations & 32 \\
\hline Credit unions & 103 \\
\hline Business incubators & 34 \\
\hline Insurance companies & 32 \\
\hline Brokerage offices & 1424 \\
\hline
\end{tabular}

As it can be seen from the information, the amount of loans directed to small business and private entrepreneurship has grown by almost 11 times in 2010-2016.

Also, the rapid development of small business and private entrepreneurship has a significant impact on the establishment and maintenance of infrastructure facilities serving it.

Today, about 8,000 infrastructure companies and more than a dozen types of services are provided to the country's small business, creating the necessary conditions. 


\begin{tabular}{|c|c|c|c|c|c|c|}
\hline \multirow{4}{*}{ Impact Factor: } & ISRA (India) & $=3.117$ & SIS (USA) & $=0.912$ & ICV (Poland) & $=6.630$ \\
\hline & ISI (Dubai, UAE & $=0.829$ & РИНЦ (Russia & $=0.156$ & PIF (India) & $=1.940$ \\
\hline & GIF (Australia) & $=0.564$ & ESJI (KZ) & $=8.716$ & IBI (India) & $=4.260$ \\
\hline & JIF & $=1.500$ & SJIF (Morocco & $=\mathbf{5 . 6 6 7}$ & OAJI (USA) & $=0.350$ \\
\hline
\end{tabular}

As a result, the results of small businesses and private entrepreneurship are becoming increasingly important in the country as the most important factor of creating new jobs, raising incomes and wellbeing of the population. In particular, 391.8 thousand $(41.7 \%)$ of the total number of new jobs created in 2016 are created in the sphere of small business and private entrepreneurship. This is $4.7 \%$ more than in the previous year. Almost 21 percent of the total number of new jobs was created through the introduction of home-based work in various forms, 7.5 percent in commissioning of new facilities, reconstruction and expansion of existing ones and implementation of additional measures to increase the number of vacancies. As a result, the share of employed persons in SEE in total employment in 2015 was 73.1 percent versus 74.2 percent in 2016 .

It is seen that in the context of the global financial and economic crisis, our country is becoming an important factor in accelerated development of small business and private entrepreneurship, ensuring economic growth, creating new jobs, raising the incomes and well-being of the population.

According to the Decree of the President of the Republic of Uzbekistan of February 1, 2017 "On Additional Measures to Improve the Mechanisms for Public Services to Business Entities", the implementation of the registration of 16 types of permits for business activity without departure from other agencies for the entrepreneurial activity by "Single Window" Centers, which helps save time and material costs of business entities. In order to expand this positive experience it is planned to gradually introduce the mechanism of registration of additional 86 types of licenses and permits through "Single window" centers.

In addition, since January 1, 2018, the registration of licenses and permits issued through the "Single window" centers on the special form of paper was canceled. At the same time, the information about the issued, suspended, revoked, reissued, canceled, as well as the validity of permits and licenses were obtained through a complex of information systems "License".

A complex of information systems, starting from the first quarter of 2017 :

- to receive public services on a "single window" principle without visiting the relevant government agency;

- to remotely access information about the order and terms of obtaining permits and licenses, as well as in the Register of Permits and Licenses;
- The process and results of the review of public services and licensing applications through "OneStop-Shops" centers, regardless of where and how they are addressed, provide opportunities for monitoring.

In 2016, nearly 2,000 vacancies revealed as a result of inventory were leased to small businesses. In the last few years, the state-owned assets were sold at the zero redemption price.

In conclusion, the socioeconomic status of subjects of small business and private entrepreneurship has considerably improved in the years of independence in connection with the creation of economic and legal basis for the development of small business and private entrepreneurship. However, despite the results of the work done, there are still problems in this area. Development of small business and private entrepreneurship in all regions of the country is the basis of economic stability. Improving the process of attracting innovative capacities, investments and modern technologies in the small business and private entrepreneurship entities, upgrading the qualification of specialists is urgent.

\section{New forms of entrepreneurial activity and changes in them}

The food industry plays an important role in ensuring the economic development of the country. Today, changes in this field are positive and the development of the basis of the process of denationalization and radical change of ownership. In recent years, the number of non-governmental foodstuffs has grown significantly over the public sector. This tendency will be maintained (Table 1).

The food industry is a broad branch of the national economy, which includes meat, milk, oil, fat, fish products, flour, macaroni, canned fruits and vegetables, juices, various beverages, sugar, confectionery products, and other enterprises that produce. But what forms of food entrepreneurship will take the lead in the long term? This question can be considered in the light of the current level of development of the food industry.

In economic literature, the forms of entrepreneurship and private entrepreneurship are highlighted. It also differs depending on the type of entrepreneurial activity that is divided into individual, family, joint-stock companies, small business and private entrepreneurship. 


\begin{tabular}{|c|c|c|c|c|c|c|}
\hline \multirow{4}{*}{ Impact Factor: } & ISRA (India) & $=3.117$ & SIS (USA) & $=0.912$ & ICV (Poland) & $=6.630$ \\
\hline & ISI (Dubai, UAE & $=0.829$ & РИНЦ (Russia & $=0.156$ & PIF (India) & $=1.940$ \\
\hline & GIF (Australia) & $=0.564$ & ESJI (KZ) & $=8.716$ & IBI (India) & $=4.260$ \\
\hline & JIF & $=1.500$ & SJIF (Morocco & $=\mathbf{5 . 6 6 7}$ & OAJI (USA) & $=0.350$ \\
\hline
\end{tabular}

Table 2. Distribution of food enterprises by forms of ownership (in\%)

\begin{tabular}{||l|c|c|c|c|c|c|c|}
\hline Businesses & $\mathbf{2 0 0 3}$ y. & $\mathbf{2 0 0 7}$ y. & $\mathbf{2 0 1 1}$ y. & $\mathbf{2 0 1 4}$ y. & $\mathbf{2 0 1 6}$ y. & $\mathbf{2 0 1 7} \mathbf{~ y . ~}$ \\
\hline Total & $\mathbf{1 0 0}$ & $\mathbf{1 0 0}$ & $\mathbf{1 0 0}$ & $\mathbf{1 0 0}$ & $\mathbf{1 0 0}$ & $\mathbf{1 0 0}$ \\
\hline Public sector food businesses & 10,4 & 10,0 & 8,0 & 7,0 & 5,4 & 4,9 \\
\hline Non-governmental food businesses & 89,6 & 90,0 & 92,0 & 93,0 & 94,6 & 95,1 \\
\hline \multicolumn{3}{|c|}{ Including } \\
\hline Private property of citizens & 42,3 & 32,5 & 28,1 & 20,8 & 20,1 & 20,5 \\
\hline Business associations & 0,4 & 0,4 & 0,5 & 0,4 & 0,3 & 0,3 \\
\hline Joint ventures, foreign citizens and organizations & 1,7 & 1,2 & 1,0 & 0,9 & 0,7 & 0,6 \\
\hline Other types of non-governmental property & 45,2 & 55,9 & 62,4 & 70,9 & 73,5 & 73,7 \\
\hline
\end{tabular}

Source: Statistical Review of the Republic of Uzbekistan. - Tashkent, 2018. -S. 27.

It is divided into entrepreneurship in trade, manufacturing, public catering and service sectors.

Local entrepreneurs in Uzbekistan have expressed their views on business forms. In particular, S. Gulyamov pointed out the following forms of entrepreneurial activity: Private entrepreneurship is organized by physical or legal persons (enterprises) on the basis of their own (private) property; collective entrepreneurship - is organized on the basis of collective property of the group of citizens; mixed business - is organized on the basis of consolidation of property of one (or more) legal entity (enterprise) and several physical entities; joint venture is created by consolidation of property of two or more legal entities (including foreign enterprises); contractual entrepreneurship - is carried out on a contractual basis by the head of the enterprise without the owner (or other responsible person - manager); the head of the enterprise (or the manager) shall be registered in the proper manner to the businessman and shall have the same responsibilities [3, 12].

Q. Muftaydinov points out the following forms of entrepreneurship: Private entrepreneurship, based on individual labor activity; Private entrepreneurship, implemented by some citizens on the basis of hired labor; collective entrepreneurship carried out by a group of citizens; joint entrepreneurship, which is carried out on the basis of consolidation of legal entities and citizens' property and property rights [9, 22].

R.Gaybullaev describes the existing forms of entrepreneurship and the subjects of the entrepreneurship in Uzbekistan as follows: Private entrepreneurship and individual entrepreneurship; joint-stock companies entrepreneurship; entrepreneurship of leasehold farms and shirkats; farming business; entrepreneurship of production cooperatives; entrepreneurship of state-owned enterprises; entrepreneurship of non profitnongovernmental organizations; Entrepreneurship with joint ventures with foreign capital [2, 55-56].
V. Shepelev described the following in the classification of the main forms of entrepreneurship and business: [14, 7]: according to the source of entrepreneurship; according to administrative and legal forms; in terms of legal regulation; according to innovation level of goods and services.

In the conditions of modernization and diversification of the economy, the food industry needs to improve the internal system of entrepreneurship. Therefore, when looking at an entrepreneurial activity as an internal system, it does not mean that it is a purely economic relationship, and other elements are also part of it (Graph 1).

Entrepreneurship in the food industry develops through joint-stock companies, small businesses, micro-firms and individual entrepreneurs. Therefore, some economists think that they are the cornerstone of the present-day economy, while others believe that state-owned and large-scale food producing companies are creating conditions for small businesses. Each of these views has a specific foundation.

This is determined by the historical development of food business, its emergence as a economic and legal entity in class.

The system of state control and support for entrepreneurship in Uzbekistan has been improving and improving from year to year. The procedure for registration of business entities has been simplified, the number of transactions is reduced and reached to a minimal level.

According to the International Monetary Fund experts, the average duration of a new business registration in Uzbekistan in 2016 will be about 6 days, while the number of transactions is $5[15,7]$. Although Uzbekistan's rating is lower than the developed countries, it is quite high among developing countries.

In summarizing the above research, the first group of scholars suggests that economic relations can be established through exchange relations and that 


\begin{tabular}{|c|c|c|c|c|c|c|}
\hline \multirow{4}{*}{ Impact Factor: } & ISRA (India) & $=3.117$ & SIS (USA) & $=0.912$ & ICV (Poland) & $=6.630$ \\
\hline & ISI (Dubai, UAE & $=0.829$ & РИНЦ (Russia & $=0.156$ & PIF (India) & $=1.940$ \\
\hline & GIF (Australia) & $=0.564$ & ESJI (KZ) & $=8.716$ & IBI (India) & $=4.260$ \\
\hline & JIF & $=1.500$ & SJIF (Morocco & $=\mathbf{5 . 6 6 7}$ & OAJI (USA) & $=0.350$ \\
\hline
\end{tabular}

foodstuffs will be sold and processed, while the second group of scientists will focus on the financial, economic, commercial, tax and other activities and events and provide a wide range of food products to the public.

\section{Conclusion}

The results of our scientific researches, scientific-theoretical analyzes can be summarized in the following general conclusions based on comparative comparisons of thinkers of entrepreneurial activity, the views of mature scientists:

- further enrichment of entrepreneurship in the entrepreneurial food industry on the basis of eastern economic thought, national spirituality and Islamic values;

- fundamental research of the peculiarities, the scientific and theoretical and practical methods of entrepreneurship in the food industry;

- Scientifically-practical study of the aspects of food industry entrepreneurship in agricultural production, the advantages of the farmer's movement, the areas of livestock production;

- To examine the relationship between the human factor related to the human development of the food industry and the state support to market economy laws.

Organizational mechanisms play a key role in providing regulation as a method for implementing an anti-field strategy. The most important requirement for the latter is expressed in mutual complementarity and interconnection, the possibility of transition from one legal regime of economic activity in the industry to another.

The initiator of the introduction of regulation, which provides a legitimate basis for it, is the state. Practically in any law providing for the introduction of regulation in a particular industry, should be reflected such issues as:

* regulatory objectives;

* boundaries of the economic sector covered by regulation; the status and powers of the government body that regulates.

The competence of the latter includes the determination of competitive methods, the choice of instruments of state influence. Meanwhile, at present, the development and maintenance of competitive relations on a purely economic basis is impossible. This requires an extensive state-legal mechanism and a developed awareness of consumer rights among the population. The formation of these institutions, the training of personnel for them, the formation of a corresponding mentality among wide sections of the public require a certain, very long time, which in the USA, for example, was about 20 years.

It seems that at the present stage, the practical efforts of the state to demonopolize should be focused on two directions. First, on the basis of the antimonopoly legislation existing in the country, it is necessary to form a competitive supplier pricing mechanism (free competition, monopolistic competition, "weak" oligopoly) providing the market in which this is possible, based on economic efficiency. To do this, it is necessary to disassemble economic structures to the size that ensures competition in the market to which they supply their products. Moreover, such a process should affect the economic structures of all forms of ownership and be carried out regardless of how far privatization has gone in this or that industry.

Secondly, antitrust regulation should be extended to enterprises that in the conditions of a planned economy were designed and built as monopoly suppliers of goods and services produced on them and cannot be divided into independent firms without significant losses in production efficiency. Given the lack of investment, the introduction of competing firms in a number of industries is unlikely, and such enterprises will probably remain a monopoly position for a long time. In fact, this makes them natural monopolies. Their transition to a market economy system and, in particular, in the sphere of pricing, is possible only in the way of maintaining control over prices for a sufficiently long time. It should be emphasized that under price control we have in mind not a direct state pricing, but a set of measures aimed at maintaining prices at a level that ensures social stability and preservation of a single economic space in the country.

Conducting an active social policy by the state together with measures to revitalize production and enter the path of economic recovery will ensure in the long term the approach of the level and quality of life of the population to the criteria of a post-industrial society. And the main lever for strengthening the role of the state in the implementation of these goals should be an active policy of comprehensive support for business activities. 


\begin{tabular}{|c|c|c|c|c|c|c|}
\hline \multirow{4}{*}{ Impact Factor: } & ISRA (India) & $=3.117$ & SIS (USA) & $=0.912$ & ICV (Poland) & $=6.630$ \\
\hline & ISI (Dubai, UAE & $=0.829$ & РИНЦ (Russia & $=\mathbf{0 . 1 5 6}$ & PIF (India) & $=1.940$ \\
\hline & GIF (Australia) & $=0.564$ & ESJI (KZ) & $=8.716$ & IBI (India) & $=4.260$ \\
\hline & JIF & $=1.500$ & SJIF (Morocco & $=5.667$ & OAJI (USA) & $=0.350$ \\
\hline
\end{tabular}

\section{References:}

1. Smith, A. (1993). Study on the nature and causes of the wealth of nations (books 1-3). Moscow: Science.

2. Samuelson, P. (2002). Fundamentals of economic analysis. SPb: School of Economics.

3. Selected, X., \& Temmen, R. (1994). Basics of the theory of economics: a textbook: trans. with him. G.I. Arutyunov, V.P. Yudentsov. Moscow: Delo LTD.

4. Hayek, F. (2000). Individualism and economic order. Moscow: Izograf.

5. Porter, M. (2005). Competition. Moscow: Williams.

6. (n.d.). Action strategy for the further development of the Republic of Uzbekistan on 2017-2021 years.

7. (2017). Statistical Bulletin of Uzbekistan for 2017 December-January.

8. Ismailov, O. S. (2012). Food Entrepreneurship Competitiveness industry of Uzbekistan. Monograph. Tashkent.

9. Khalilov, N. (2017). Introduction of quality management and ensuring its effectiveness as a factor ensuring the success of enterprises in the competitive struggle. www.biznesdaily.uz/3(111)

10. Khalilov, N. (2014). Organizational and economic mechanisms for the development of quality management system at industrial enterprises. Monographs. Tashkent: Publisher.

11. Ergashhodzhaeva, S. (2013). International competition. Educational manual. Tashkent: TDIU.

12. Meskon, M. H., Albert, M., \& Hedouri, F. (2009). Fundamentals of Management. Moscow: The Case.

13. Porter, M. (2007). Competitive Strategy: A Methodology for Analyzing Industries and Competitors. Per. sang - 3 ed. - Moscow: Alpina Business Books.

14. Smith, A. (1998). An Inquiry into the Nature and Causes of the Wealth of Nations. A selected Edition. Edited with an Introduction and Notes by Kathryn Sutherland. Oxford Worlds Classics. Oxford University press.

15. Cauchik, M. (1998). The Strategic Role of Quality Management in the Brasilian Auto Parts Industry: An Empirical Study. In Strategic Management of Manufacturing Value Chain.Ed. by Bititci U. Kluwer Academic Publishers, Norwell, MÀ.

16. Porter, M. E., \& Spence, M. (1978). Capacity Expansion in a Growing Oligopoly: The Case of
Corn Wet Milling," Discussion paper, Harvard Graduate Scool of Business Administration.

17. Kotler, P. (1972). Marketing Management. 2 nd ed. Englewood Cliffs. N. J.: Prentice-Hall.

18. Hayek, F. A. (1945). The Use of Knowledge in Society. American Economic Reviw, V.35, Sept. 4.

19. Alimov, R. K., Bayxonov, B. T., Ishnazarov, A. I., \& Imomov, J. O. (2014). Econometric modeling of the effective use of investments in enterprises. Educational manual. (p. 104). Tashkent: Science and Technology.

20. Vladimirova, L. P. (2005). Prognosing and planning. (p.314). Moscow: Dashkov.

21. Gorchakov, A. A., \& Orlova, I. V. (1995). Computational economics-mathematical model. (p.225). Moscow: Computer.

22. (2017, Dec. 22). Application of the President of the Republic of Uzbekistan Shavkat Mirziyoev to the Oliy Majlis. Tashkent.

23. (2017). Decree of the President of the Republic of Uzbekistan dated January 17, 2017 "On Measures to Accelerate the Sale of State Property for Operational Purposes and Further Simplification of its Procedures".

24. (2017). Decree of the President of the Republic of Uzbekistan from February 1, 2017 "On Additional Measures to Improve Mechanisms for Public Services to Business Entities".

25. (n.d.). Decree of the President of the Republic of Uzbekistan dated February 7, 2017 "On the Strategy for the Further Development of the Republic of Uzbekistan" February 8, 2011 // Public Sector.

26. (n.d.). The State Program of the President of the Republic of Uzbekistan "On the Implementation of the Strategy of Action on the Development of the Republic of Uzbekistan in Five Priority Directions for the Development of the Republic of Uzbekistan in 2017-2021, the Year of Support for Active Business, Innovation Ideas and Technologies" dated January 22, 2018.

27. (2012). The Decree of the President of the Republic of Uzbekistan of July 18, 2012 "On further improvement of the work environment and promotion of entrepreneurship." www.Iex.uz

28. (2016). Decree of the President of the Republic of Uzbekistan dated October 5, 2016 "On additional measures to ensure accelerated development of entrepreneurship, comprehensive protection of private property and qualitative improvement of the business environment". www.Iex.uz 


\begin{tabular}{|c|c|c|c|c|c|c|}
\hline \multirow{4}{*}{ Impact Factor: } & ISRA (India) & $=3.117$ & SIS (USA) & $=0.912$ & ICV (Poland) & $=6.630$ \\
\hline & ISI (Dubai, UAE & $=0.829$ & РИНЦ (Russia & $=\mathbf{0 . 1 5 6}$ & PIF (India) & $=1.940$ \\
\hline & GIF (Australia) & $=0.564$ & ESJI (KZ) & $=8.716$ & IBI (India) & $=4.260$ \\
\hline & JIF & $=1.500$ & SJIF (Morocco & $=5.667$ & OAJI (USA) & $=0.350$ \\
\hline
\end{tabular}

29. (2017). Resolution of the President of the Republic of Uzbekistan "On Additional Measures to Improve Mechanisms for Public Services to Business Entities" of February 1, 2017. www.Iex.uz

30. (2017). Resolution of the President of the Republic of Uzbekistan "On Measures for Further Expansion and Simplification of Microcrediting System for Small and Private Entrepreneurship" as of January 31, 2017. www.Iex.uz

31. (2017). Decree of the President of the Republic of Uzbekistan dated January 17, 2017 "On measures to accelerate the sale of state-owned objects for business use and further simplification of its procedures". www.Iex.uz

32. (2017, September 20). Speech of Sh.M.Mirziyoev at the 72nd Session of the United Nations General Assembly on 19 September 2017. People's Word.

33. Mirziyoev's, S. M. (2017, December 23). appeal to the Oliy Majlis. People's Word.

34. Khusainov, G. L. (2015, January-February). Opportunities to Improve the Mechanism of Financing Small Business and Private Entrepreneurship Electronic. Electronic Journal "Economics and Innovative Technologies". No 1 .

35. Gaybullaev, R. M. (2005). Improving the economic mechanism of entrepreneurship development in the Republic of Uzbekistan: ICT. fan dock dis. (pp.55-56). Tashkent: Uz.Res. FAII.

36. G'ulomov, S. (2002). Entrepreneurship and small business. (p.12). Tashkent: East.

37. Zinchuk, G. M. (2008). Food market development: theory, methodology, practice: Author's abstract. dis .. doc econ Sciences.Saransk, p.8.

38. Ivatov, I. (1994). Development of the dekhkan market in Uzbekistan. (p.112). Tashkent: Fan.
39. Kamilova, F. K. (2003). Uzbekistan consumer market and the role of demographic factors in its development: Author's abstract. dis. ... doc econ Science. (p.43). Tashkent: AGOS.

40. Kiseleva, E. N., Vlasova, O. V., \& Konnova, E. B. (2013). Market of food products. Tutorial. (p.144). Moscow: University textbook.

41. Madiyarov, G. A. (2008). Development of a marketing system in the consumer goods market (eg foodstuff): ICT. fan title dis avtoref. (p.23). Tashkent: TDIU.

42. Muftaydinov, Q. H. (2004). Problems of entrepreneurship in conditions of economic liberalization: ICT. fan doc., dis ... (p.22). Tashkent: MUO'MU.

43. Muhiddinova, U. S. (2010). Directions of development of the market of fruit and vegetable products under the conditions of modernization of economy: the science of economics. dock ... dis. avtoref. (p.37). Tashkent: BMA.

44. Stukanova, I. P. (2009). Marketing management of the regional consumer market of food products (on the example of the Volga Federal District): Author's abstract. dis. doc econ Science. Moscow. p.13.

45. Shepelov, V. M. (1996). Entrepreneurship in a Market Economy. Taxpayer Journal, Tashkent, No. 7, p. 745.

46. (2017). Doing Business 2016 Uzbekistan. The World Bank. p.7. www.doingbusiness.org

47. Ismailov, O. S. (2012). Entrepreneurial Competitiveness of the Food Industry of Uzbekistan. Monograph. Tashkent.

48. Ibragimov, I. U., \& Tursunov, B. O. (2017). Enhancement the mechanism of analyzing of the methodological principles for the development and improvement of methods of assessment. Audit, № 4, pp.11-13.

49. Tursunov, B. O. (2017). Osnovnye napravleniya podderzhki malogo biznesa $\mathrm{v}$ Uzbekistane I zarubezhnyy opyt razvitiya predprinimatel"stva. Audit, № 6, pp. 34-38. 